\title{
Identification of Indian Sida through mericarp
}

\author{
Kumar Avinash Bharati \\ Central National Herbarium, Botanical Survey of India, Howrah, INDIA.
}

\begin{abstract}
Background: some of the species of Sidaare being used as medicine in traditional therapies and available in the market as broken plant parts. Therefore, adulteration is very common. A study was conducted to identify the Indian Sida L. through morphological features of mericarp found in the market samples. Methodology: the fruits of Sida are collected from field in flowering and fruiting stage. The identity of the species were determined and dried mature fruit (schizocarp) of specimens were dissected and studied under compound microscope. The market samples were purchased from various parts of the India and fruits were investigated to match the key characters have been found during the study. Results: mericarp of Sida possess huge diversity and it is a reliable character for identification. Each species of Sida has unique mericarp structure. However, some of the species like, Sida alba have four different types of mericarp but they different from
\end{abstract}

mericarps of other species. I have come across with 27 different types of mericarps in Indian Sida. Conclusion: mericarp morphology is a key character to determine the identity of the species. Based on mericarp features a bracketed dichotomous key has been prepared for identification. The species of Indian Sida may be identified the help of mericarp morphology.

Keywords: Sida, India, Mericarp, Sida cordifolia.

Corresponding author: Kumar Avinash Bharati, Central National Herbarium, Botanical Survey of India, Howrah-711103, INDIA.

Phone: +91-9968703038

Email: k.avinash@hotmail.com

DOI : 10.5530/pj.2016.5.14

\section{INTRODUCTION}

Few species of Sida are used in different traditional systems medicines and sold in market. The demand is high and drugs are sold as broken plant parts, adulteration is very frequent in crude drug market. ${ }^{1}$ To avoid frequent adulteration the identification of Sida species through mericarp is very necessary. These adulterants are responsible to deteriorate the quality and efficacy of the drug. Moreover, they may cause deleterious effect on human health. ${ }^{2}$ The most commonly sold species is Sida cordifolia (seeds are being used as Ayurvedic drug named "Bala"). Sida cordifolia is being frequently adulterated with other species of Sida such as Sida rhombifolia, Sida cordata, Sida spinosa and Sida alba. ${ }^{3}$ Some other species are also being used as medicine: Sida acuta, Sida rhombifolia, S. spinosa, S. veronicaefolia, S. ovate. ${ }^{1,3-7}$

Some of the sporadic publications on pharmacognosy of Sida cordifolia, Sida spinosa and Sida rhombifolia are available but they are based on characters of root anatomy, chemistry, trichomes and dedicated to single species. ${ }^{8-12}$ Sivarajan et al., in J. Taiwan Mus. 45(1):65-73(1992), published mericarp morphology of Indian Sida in relation to plant taxonomy, ${ }^{13}$ though it is a good study but not useful in crude drug identification because: (1) it is mainly based on fresh collections; (2) descriptions are not suitable for pharmacognosy; (3) identification key is not provided; (4) some of the species given are not recognized by Flora of India ${ }^{14}$ and few species are merged and few species names falls under unresolved category; (5) after that some new species in genus Sida have been added. Paul and Nayar had studied seed coat of seven species of Sida through Scanning Electron Microscope (SEM) but it is different from pharmacognosy of the species. ${ }^{15}$ Further, SEM a is sophisticated technology not easily available. The pharmacognosy of either all the Indian Sida or pharmacognosy through fruit or mericarp morphology are hitherto unknown. The DNA markers and phytochemical studies may resolve such issues but they are costly and time consuming as compared to morphological studies. ${ }^{16-18}$

The Sida fruit is a schizocarp which splits away at maturity in to mericarp. The mericarp is the seed-containing part of a fruit that do not form a single unit. It has been observed that fruit (mericarps) of Sida species show significant variation from species to species. As per Waalker, mericarp char- acter is more reliable key character than highly plastic foliar and stipular characters. ${ }^{19}$ The fruits or mericarps or both may be selected by careful examination of the market drugs and the identity of the species may be establish with the help of compound microscope.

The study was designed to test the hypothesis: each and every species of Sida are unique in mericarp morphology. Therefore, present study was focused on identification of market samples of Sida species through morphological studies to achieve following objectives:

(a) authentication of the crude drugs sold in market as Bala (Sida cordifolia) and other species of Sida through morphological studies of mericarp;

(b) development of identification key for India's Sida using morphological features of mericarps.

\section{Methodology}

The fruits of Sida are collected from field in flowering and fruiting stage. The identity of the species were confirmed through traditional taxonomic studies, and matched with authentic specimens submitted in Central National Herbarium (CAL) and Flora of India. ${ }^{14}$ The dried mature fruit (schizocarp) of specimens were dissected and studied under Nikon SMZ 1500 microscope and photographs were taken with the help of inbuilt camera. In crude drug market, Sida species is sold in dried form therefore the dried fruits are studied to observe the similar findings. Further, market samples were collected/purchased from various parts of the India (i.e. New Delhi, Haridwar, Reshikesh, Kolkata, Jaipur, Lucknow, Coimbatore, Hyderabad and Mumbai) and fruits were studied to match the key characters which have been found during the study. Sida repens, S. elongata var. balica and S. tiagii are not re-collected after their first report. Therefore, line drawings and descriptions are given on the basis of published literatures. ${ }^{20,21}$ Similarly, I was dependent on literatures for S. linifolia and S. subcordata. ${ }^{19,22}$

\section{Observations}

It has been observed that the mericarps morphology of Sida species are varies from species to species. The mericarps of all the 14 Sida species of India have been studied to recognize key characters which may help in authentication of the specimens. 


\begin{tabular}{|c|c|c|}
\hline 1a. & Mericarp with awns... & 2. \\
\hline 1b. & Mericarp without awns ..... & 10. \\
\hline $2 \mathrm{a}$. & Awns with groove... & (i) S. acuta \\
\hline $2 \mathrm{~b}$. & Awns without groove........ & 3. \\
\hline $3 a$. & Awns with 2 spiny outgrowth.. & (ii) S. tiagii \\
\hline $3 \mathrm{~b}$. & Awns without spiny out growth.. & 4. \\
\hline 4a. & Awns up to $0.5 \mathrm{~mm}$ long...... & 5. \\
\hline $4 \mathrm{~b}$. & Awns more than $1 \mathrm{~mm}$ long............ & 8. \\
\hline $5 a$. & Awns divergent, horn like . & (iii) S. spinosa \\
\hline $5 b$. & Awns strait .................. & 6. \\
\hline $6 a$. & Awns with stellate-hairs....... & (iv) S. rhambifolia \\
\hline $6 \mathrm{~b}$. & Awns sparsely hairy.................... & 7. \\
\hline $7 a$. & 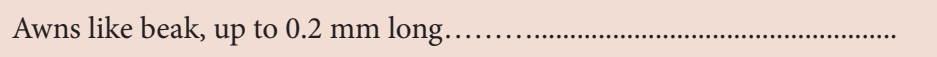 & (v) S. schimperiana \\
\hline $7 \mathrm{~b}$. & Awns $0.3-0.5 \mathrm{~mm}$ long, unequal in length............... & (vi) S. ovata \\
\hline $8 \mathrm{a}$. & Mericarp tetrahedral with rounded angles................ & (vii) S. javensis \\
\hline $8 b$. & Mericarp trigonous or flattened-trigonous...................... & 9. \\
\hline 9 a. & Awns glabrous......... & (viii) S. subcordata \\
\hline $9 \mathrm{~b}$. & Awns hairy.......................... & 10. \\
\hline 10a. & Mericarp trigonous, $1-1.25 \mathrm{~mm}$ long, awns with antrose hair .................... & (ix) S. alba \\
\hline $10 \mathrm{~b}$. & Mericarp flattened-trigonous, 2-4 mm long, awns with retrose hair.......... & (x) S. cordifolia \\
\hline $11 \mathrm{a}$. & Mericarp glabrous.................. & (xi) S. linifolia \\
\hline $11 \mathrm{~b}$. & Mericarp short hairy......................... & 12. \\
\hline $12 \mathrm{a}$. & Mericarp dorsal surface bears short hairs............. & (xii) S. elongata \\
\hline $12 \mathrm{~b}$. & Mericarp apex bears short hairs................... & 11. \\
\hline $13 a$. & 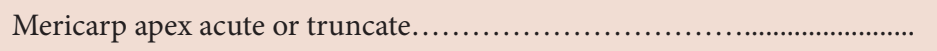 & (xiii) S. mysorensis \\
\hline $13 \mathrm{~b}$. & Mericarp apex obtuse or blunt............. & (xiv) $S$. cordata \\
\hline
\end{tabular}

(i) Sida acuta Burm.f., Fl. Ind. 147.1768; Roxb., Fl. Ind. 3: 171. 1832.

Mericarps varies from 6-10 in number, more or less tetrahedral, 2-2.5 $\mathrm{mm}$ long, awn with groove, $1-1.5 \mathrm{~mm}$ long, smooth. Seeds are triangularly ovoid, dark brown in colour.

(ii) Sida tiagii Bhandari in Ann. Arid Zone 16:455. 1977.

Mericarp 7-8, reticulated on both side, rugulose on back, small, white, glandular hairs; apex hirsute with 2 awns, 2 glands and 2 spiny outgrowths just below the awn; awn $1.5 \mathrm{~mm}$ long, hirsute. ${ }^{20}$

(iii) Sida spinosa L., Sp. Pl. 683. 1753; Masters in Fl. Brit. India 1:323.1874.

Mericarps 5, trigonous, 2-3 mm long, at apex 2 horn like short awns (about $0.5 \mathrm{~mm}$ long), hairy surface, stellate hairy, more hairs near apex, pericarp partially envelope seeds and it expose bottom of the seed. Seeds are ovoid, trigonous about $1.5 \mathrm{~mm}$ long, glabrous, brownblack.

(iv) Sida rhombifolia L., Sp. Pl. 684. 1753. Emend. Masters in Fl. Brit. India 1: 323. 1874.

Mericarps 6-12, flattened, trigonous, 1-1.5 mm in size, 2 small awns, often unequal in length, stellate-hairy, usually both ventral and dorsal surface of mericarp is possess short hairs. Seeds about $1 \mathrm{~mm}$ long, flattened glabrous, reniform, brown or black.

(v) Sida schimperiana Hochst. ex A. Rich. Fl. Abyss. 1:66. 1847; Masters in Fl. Brit. India 1:322. 1874.
Mericarps 5, about 2.5-3.5 mm long, surface reticulated, 2 minute awns (short beak like structure), often glabrous, dehiscing along inner edge. Seeds about 1-1.5 mm long, glabrous, brown in colour.

(vi) Sida ovata Forssk., Fl. Aegypt.-Arb. 124. 1775; Masters in Fl. Brit. India 1:323. 1874

Mericarps 8, 3-3.5 mm long, both dorsal and ventral surface prominent reticulate and sparsely hairy, apex short-hairy, with 2 awn, awns are small in size unequal in length, about $0.5 \mathrm{~mm}$ long. Seeds about 2-3 mm long, rounded-reniform, glabrous, few hairs at hilum, brownish black in colour.

(vii) Sida repens Dombey ex Cav., Diss. 1:7. 1785; Sida javensis subsp. expilosa sensu Mathew \& Sivar. J. Econ. Tax. Bot. 4:619. 1983; Paul in Sharma \& Sanjappa (eds.), Fl. India 3:286. 1993, non Borss. 1966.

Mericarps 5, about $3 \mathrm{~mm}$ long, $1 \mathrm{~mm}$ long awns, tetrahedral with rounded angles with 2 awn, dorsal surface and awns with hairs. Seeds ovoid, 2-2.5 mm long, hilum short hairy, brown-black colour. ${ }^{19,21}$

(viii) Sida subcordata Span. [in Hook., Comp.Bot.Mag. 1:344. 1846, nom nud.] Linnaea 15:172. 1841; Borss, Blumea 14: 199. 1966.

Mericarps 8-10,3×2.5mm, laterally triangular with acute angles, black, reticulate on side and back, awns short up to $2 \mathrm{~mm}$ long, divergent, glabrous. Seeds reniform, flattened, glabrous but sparsely hairy hilum. ${ }^{19,22}$

(ix) Sida alba L., Sp. Pl. ed. 2.966.1753. 

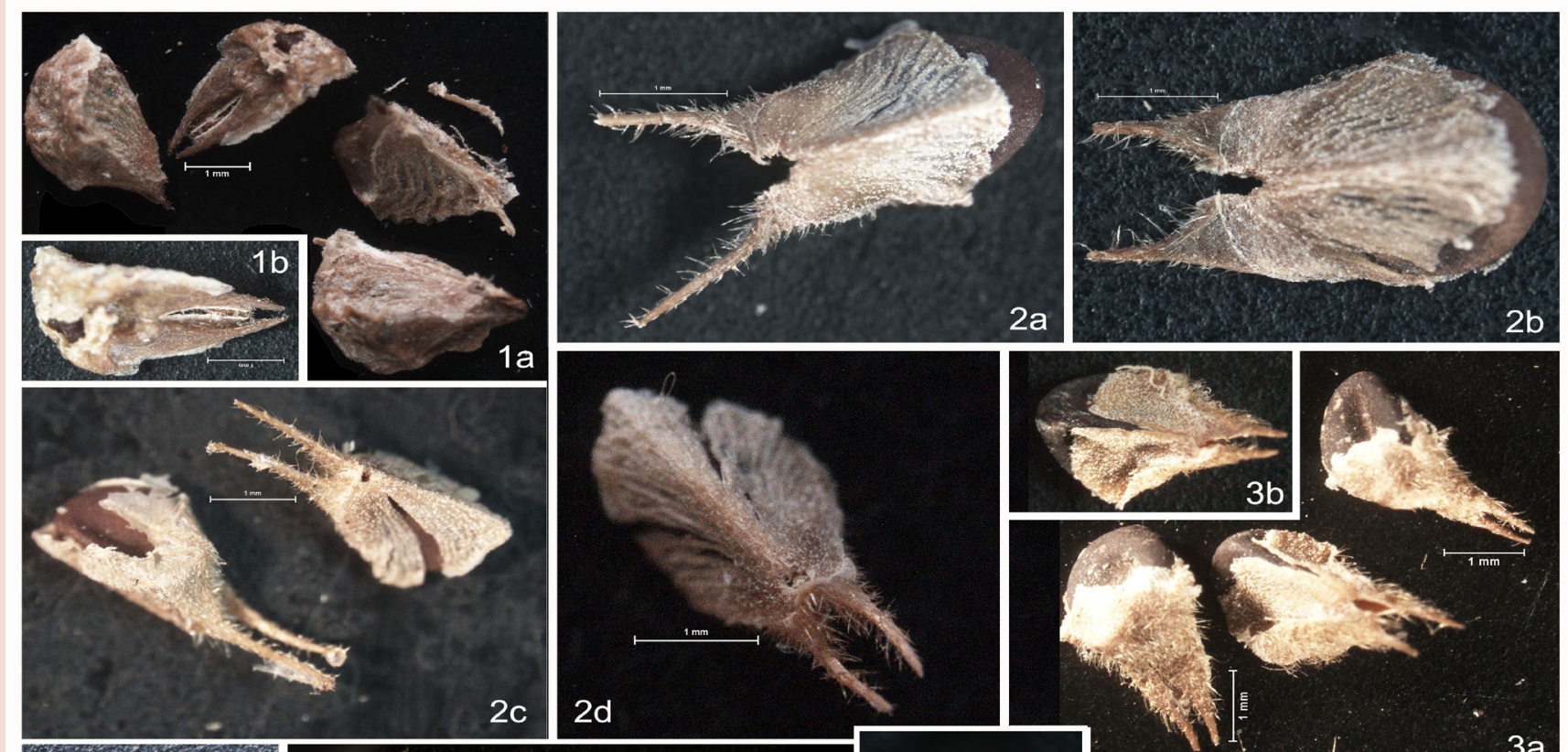

$2 b$
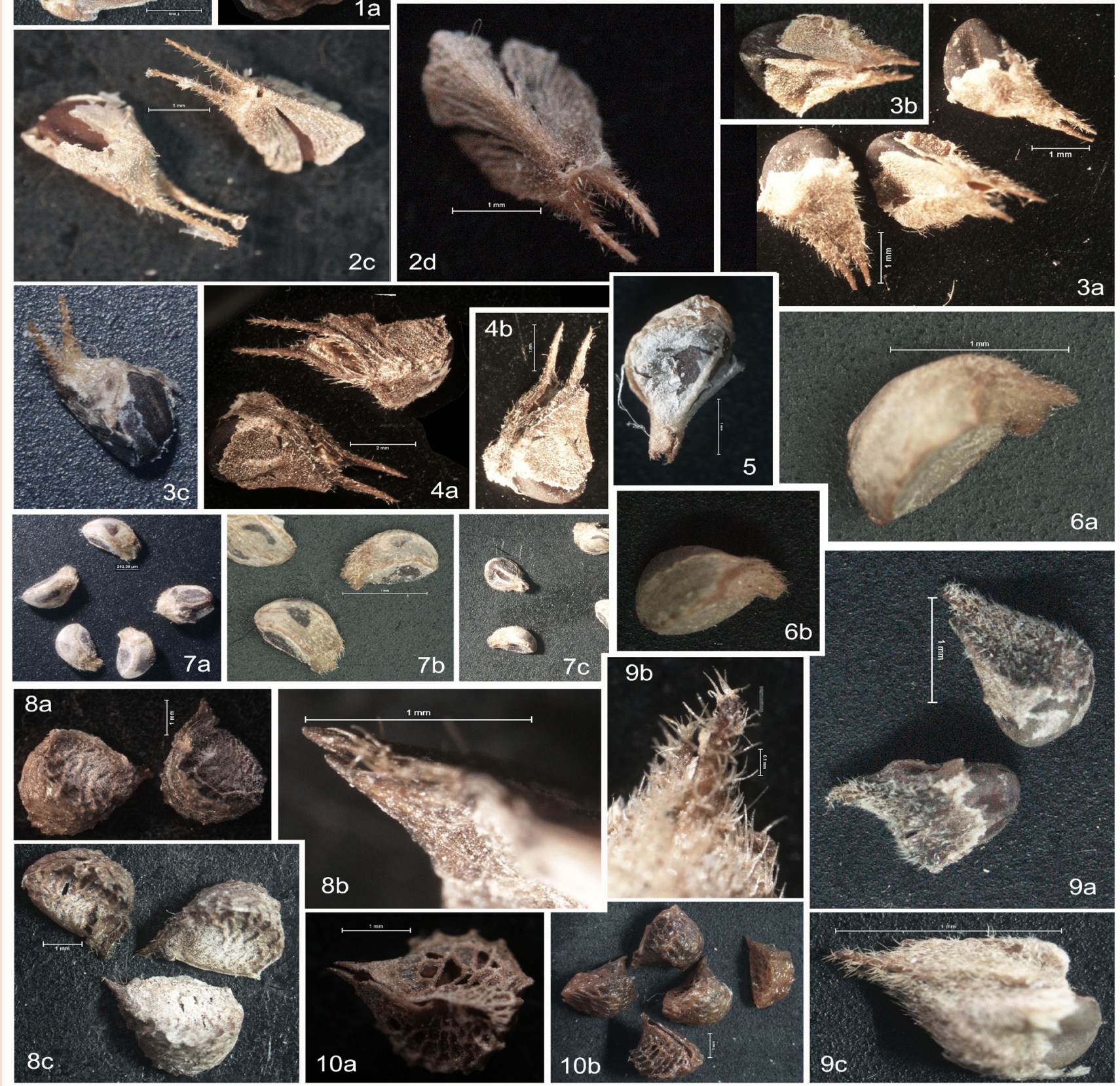

$3 a$
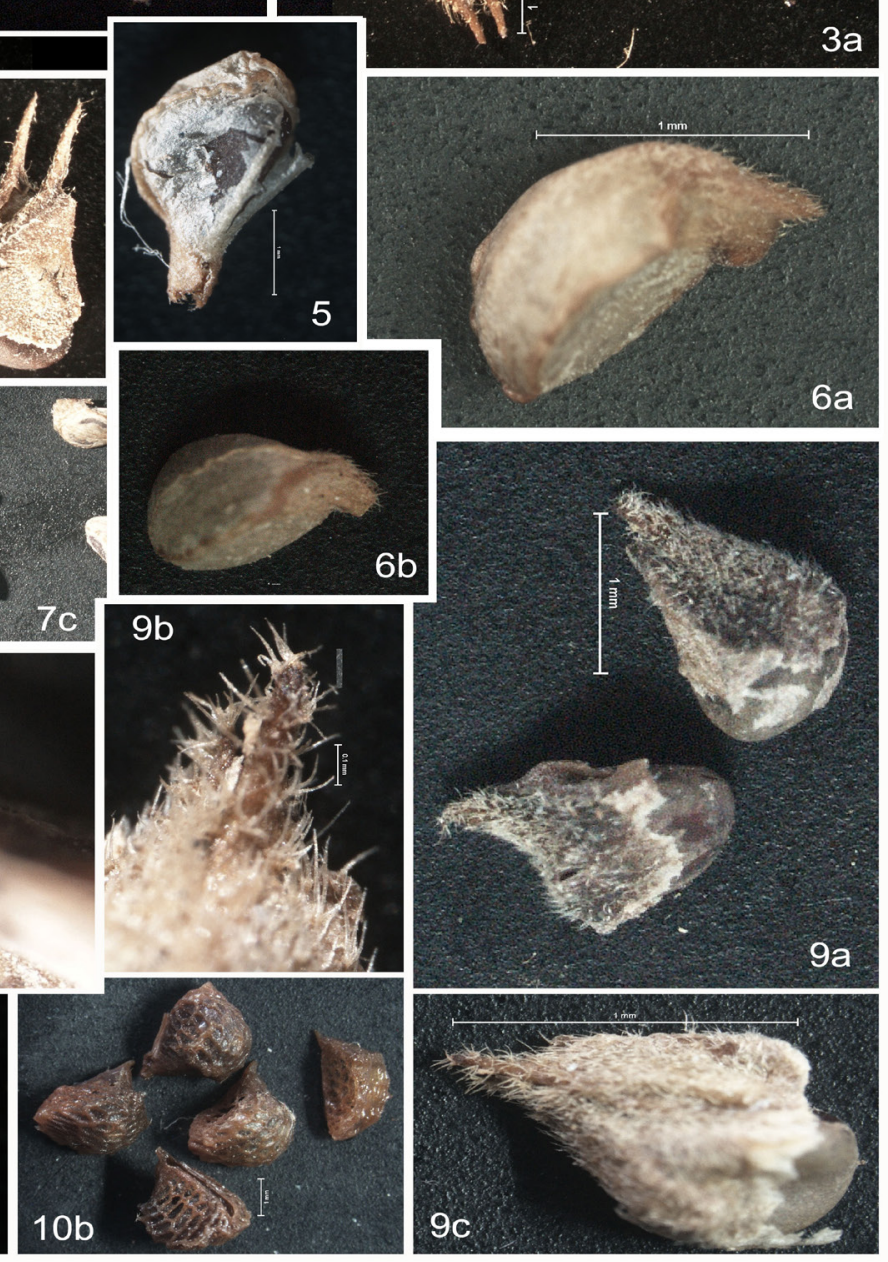

Figure 1: Mericarp morphology in Sida L.: 1, S. acuta; 2, S. alba; 3, S. spinosa; 4, S. humilis; 5, S. glutinosa; 6, S. mysorensis; 7, S. cordata; 8, S. ovata; 9, S. rhombifolia; 10, S. schimperiana. 


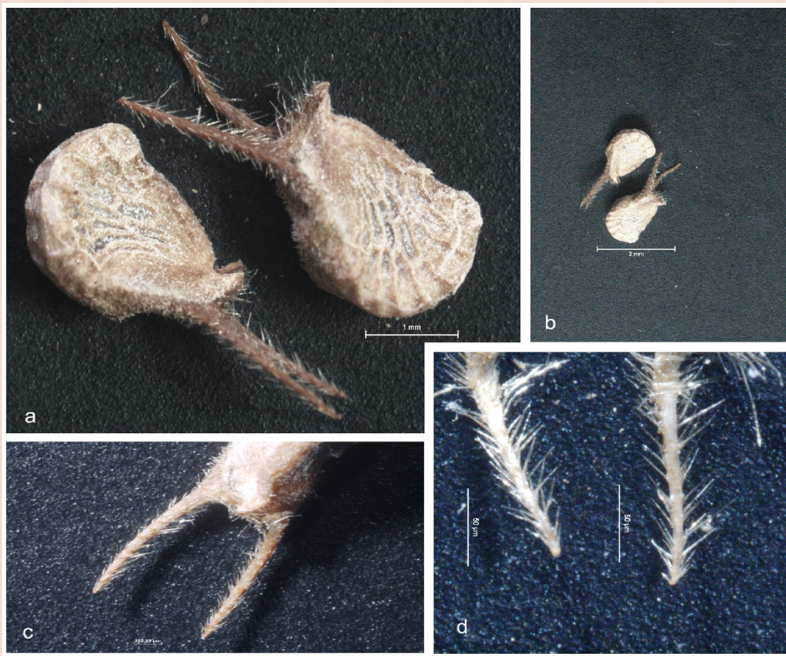

Figure 2: Mericarps of Sida cordifolia: a, mericarp with 2 awns, dorsal and ventral surfaces prominently reticulated; $b$, mericarps are flattened trigonous, brown colour, apical portion hairy, 2 long awns; c-d, awns about 2-4 $\mathrm{mm}$ long, bear retrose hairs.x.

Mericarps 5, about 2-3 mm long; 2 awns, convergent or convergent (sometimes parallel), hairy, $0.8 \mathrm{~mm}$ to $1.25 \mathrm{~mm}$ long. Seeds are about 1-1.5 mm long, glabrous, slightly trigonous, brownish-black.

(x) Sida cordifolia L., Sp. Pl. 684. 1753; Masters in Fl. Brit. India 1: 324. 1874.

Mericarps 8-10, flattened-trigonous, excluding awn about 2-3.5 mm long, brown in colour, both dorsal and ventral surface prominently reticulated and apical portion stellate hairy, apex with 2 retrosely hairy awns, awns are about 2 to $4 \mathrm{~mm}$ long. Seeds are flattened reniform about $2.5 \mathrm{~mm}$ long, glabrous but hilum bears small hairs, brown to black in colour.

(xi) Sida linifolia Juss. ex Cav., Diss. 1:14.t.2.f.1. 1785; Bol. Soc. Brot. Ser. 5 Ser. 54:7.1980; Pradeep \& Sivar., Rheedea 3: 22-25. 1993.

Mericarps 8-9, $3 \times 2 \mathrm{~mm}$, brownish-black, laterally flattened, glabrous, muticous at apex. Seeds reniform, lattened, dark brown, glabrous. ${ }^{22}$

(xii) Sida elongata var. balica (Miq.) Borss. in Blumea 14:182. 1966; Mathew \& Sivarajan in J. Econ. Tax. Bot. 4:617. 1983.

Mericarps 5, tetrahedral, slightly rounded on the angles, $2.5 \mathrm{~mm}$ long, awn absent, short dorsal hairs. Seed ovoid, slightly trigonous, glabrous, grayish. ${ }^{19,21}$

(xiii) Sida mysorensis Wight \& Arn., Prodr. 59. 1834; Masters in Fl. Brit. India 1:322. 1874. S. glutinosa Roxb., [Hort. Beng. 97. 1814, nom. Nud.] Fl. Ind. 3:172.1832.

Mericarps 5, tetrahedral with rounded angles, awnless, apex acute with short hairs (rarely apex truncate with short hairs), about 1.25-2 $\mathrm{mm}$ long, brown in colour. Seed ovoid, slightly trigonous, about 1-1.8 $\mathrm{mm}$ long, glabrous, greyish brown.

(xiv) Sida cordata (Burm.f.) Borss. in Blumea 14:182. 1966. S. humilis Cav., Diss. 5 t. 134, f. 2.1788.

Mericarps 5, tetrahedral with rounded angles, awnless, apex bear small hairs, $0.8 \times 1.8-2.2 \mathrm{~mm}$ in size, slightly elongated. Seed ovoid, brownish-black, glabrous.

\section{DISCUSSION}

Species of Sida are in India

Flora of India has given 12 species of Sida in India ${ }^{[14]}$. Sivarajan and Pradeep were proposed 17 species, however, the three species have been merged and few names are unresolved ${ }^{22-25}$ Furthermore, there are some confusion in the identity of $S$. alba and S. spinosa, some literatures consider them as conspecific whereas some as heterospecific. ${ }^{14}$ In present study two criteria have been followed to recognized the species: (1) Flora of India (1993) and (2) morphology of mericarp. It means only two species are added effectively in genus Sida i.e. S. subcordata and S. linifolia (http://www.theplantlist.org/). Therefore, 14 species of Sida are considered.

\section{Not all the species of Sida are common}

The Sida repens and S. elongata var. balica have not been re-collected after their first collection in 1983 from Nilambur forest areas of Kerala. Both the specimens are housed at Calicut University Herbarium (CALI). S. tiagii Bhandari has the similar fate, it has been not recollected after first collections in 1962 from sandy ground of Barmer, Rajasthan. The specimen is stored at $\mathrm{CNH}$, Kolkata (CAL). Therefore, line drawings and descriptions of these three species are depicted as per protologue and other published literatures. ${ }^{14,20,22,26}$ The S. subcordata was first collected from Kerala in 1996 and S. linifolia was first reported from India in 1993. Hence, the descriptions and illustrations of Sida linifolia and S. subcordata have been given as per the literature..$^{22,24}$ As these species are uncommon, chances of being used as adulterant are negligible.

\section{Mericarp of Sida display wide range of diversity}

As given in Figure 2 and 3, there are huge diversity in the mericarp of Sida. I came across with 27 different types of mericarps in Sida species. The Flora of India described the awns of Sida alba as convergent whereas in present study awns are found as divergent or convergent or parallel in orientation. ${ }^{14}$ It is the only species of India which possesses a pair of long awns with antrose hairs and great diversity in awn orientation i.e. divergent or convergent or parallel. ${ }^{14}$ The Sida cordifolia is easily identified with mericarp morphology, it bears a pair of long awn (more than $1.25 \mathrm{~mm}$ ) with retrose hairs. Some species of Sida are taxonomically merged or nomenclature is unresolved but they possess unique mericarps: Sida 


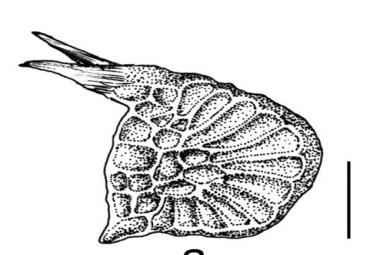

a

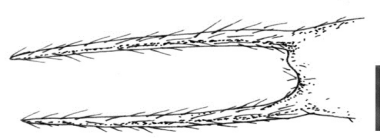

d
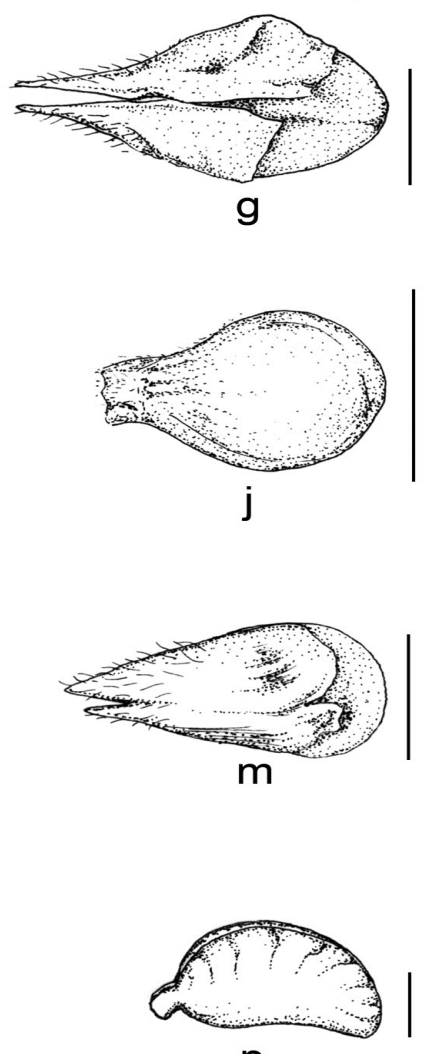

$\mathrm{p}$

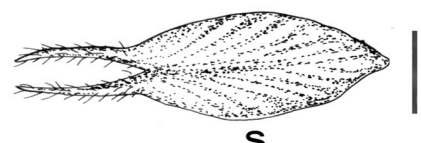

$\mathbf{S}$

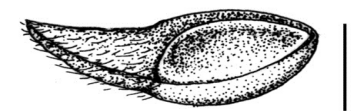

b

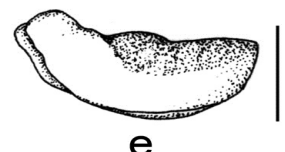

e
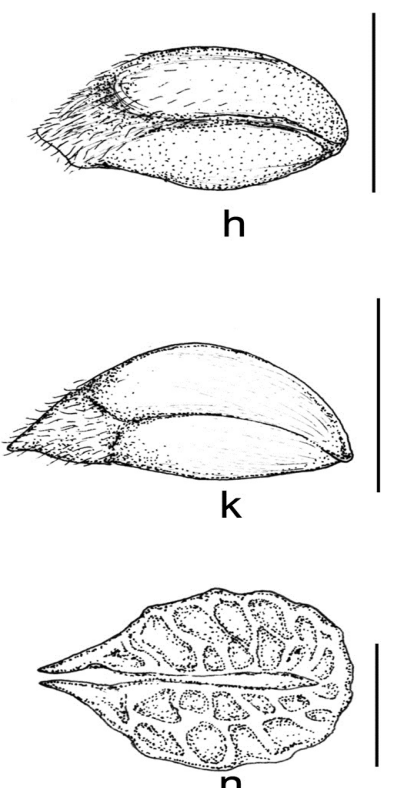

$\mathrm{n}$

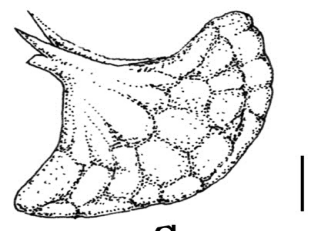

q

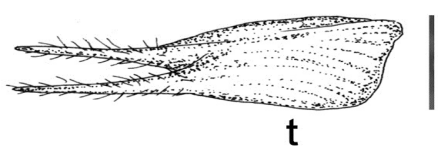

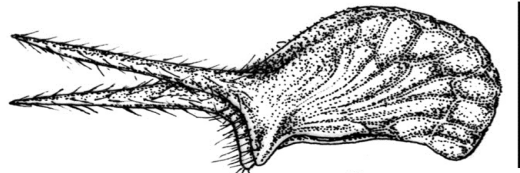

C
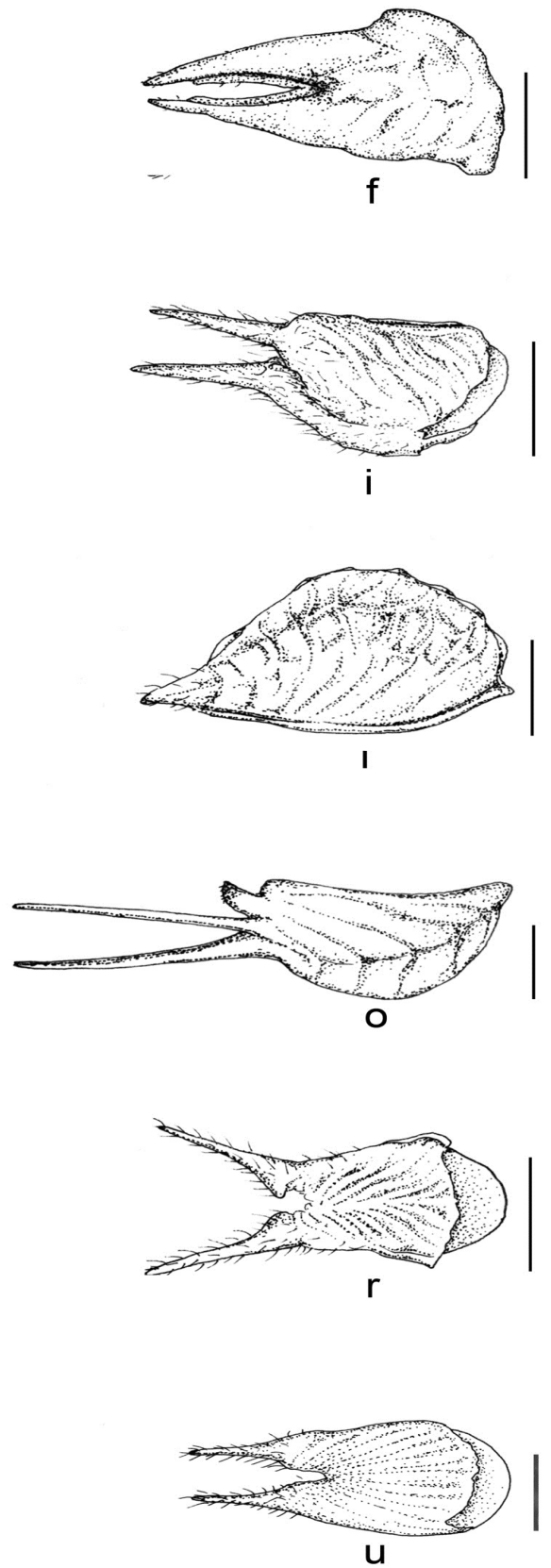

Figure 3: Mericarps of Sida species: a, S. tiagii; b, S. repens; c-d, S. cordifolia; e, S. elongata; f, S. acuta; g, S. spinosa; h, S. cordata; i, S. humilis; j, S. glutinosa; k, S. mysorensis; I, S. ovata, m, S. rhombifolia; n, S. schimperiana; o, S. fryxellii; p, S. linifolia; q, S. subcordata; r-u, S. alba. 


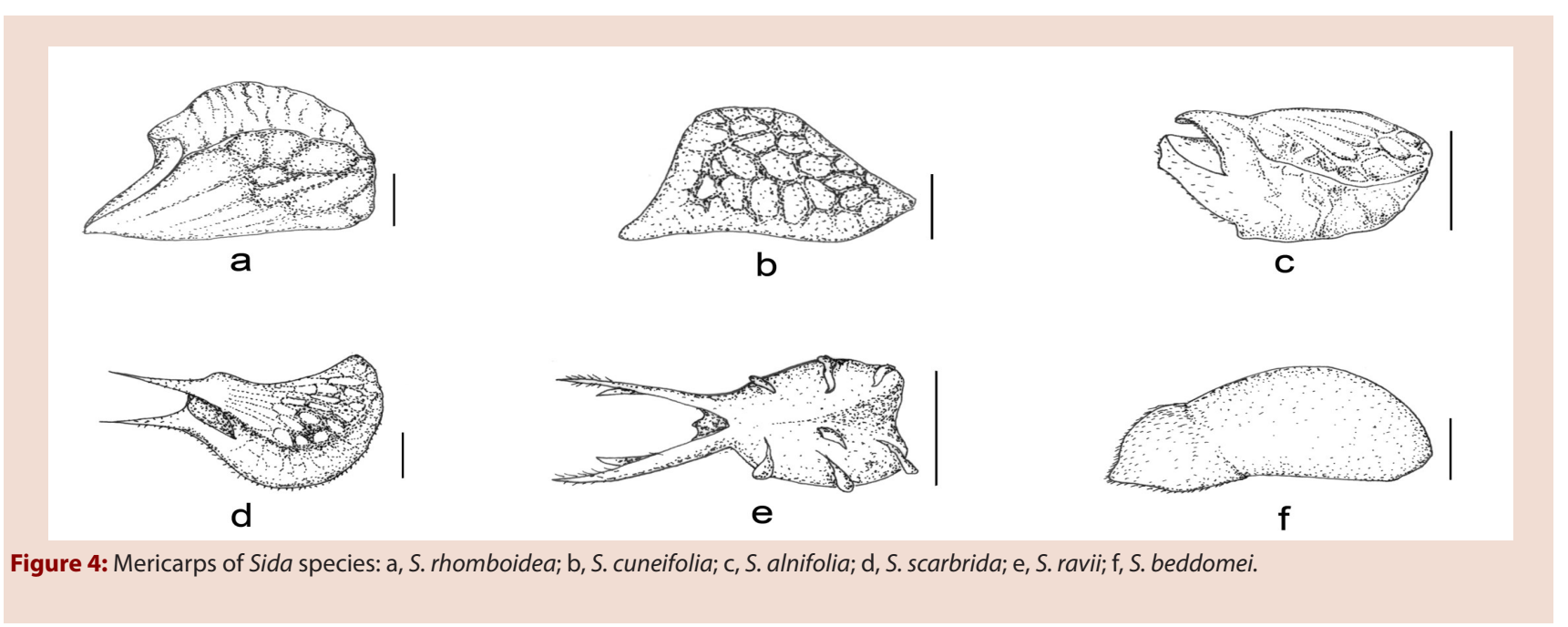

alnifolia, S. humilis, S. cuneifolia, S. beddomei, S. fryxellii, S. scarbrida, S. glutinosa, S. rhomboidea and S. ravii.

\section{Sida cordifolia and its common adulterants}

Sida cordifolia (i.e. Bala) has not shown much diversity like some other species of Sida. ${ }^{14,19,22}$ Though, Marais was proposed two subspecies from Mascarene Islands but Sivarajan and Pradeep have discarded the subspecies "..................such a classification seems to be untenable in the case of Indian specimens". ${ }^{23,27}$ Furthermore, Marais had created subspecies on the basis of flower colour and character state of leaf hairs. ${ }^{27}$ It means the mericarp morphology is not show much variation in $S$. cordifolia, which is the key character in the present study. Sivarajan and Pradeep, in Kew Bulletin 45:725-727 (1990), proposed a new record for India as S. fryxellii. ${ }^{19}$ It is an interesting species, the plant list databases considered the species name as unresolved name; this species has been merged in S. rhombifolia subsp. rhombifolia var. rhombifolia by Flora of India. ${ }^{14}$ The S. fryxellii and $S$. cordifolia mericarps morphology are very close to each other except stellate-pubescent awns (S. fryellii) and retrorsely hairy awns (S. cordifolia). This species grows intermixed with $S$. cordifolia. ${ }^{23}$ Hence, chance of unintentional adulteration is very high if collector is unskilled or careless. The S. rhombifolia, S. cordata, S. spinosa and S. alba are frequently used as adulterant for S. cordifolia. But all the common adulterants of Sida cordifolia are very different in mericarp morphology especially awns (Fig. 1-3). They are either awn less or possess different awn morphology: two small awns with stellate hairs (S. cordifolia), awnless (S. cordata), a pair of hornlike, small awns (S. spinosa) and a pair of awns, divergent or convergent, hairy, up to $1.25 \mathrm{~mm}$ long (S. alba).

\section{CONCLUSION}

The mericarp structure shows great diversity in different species of Sida. It is a key character to determine the identity of the species. The species of Indian Sida may be identified with the help of mericarp morphology. The pharmacognosy of Sida species will be useful for pharmaceutical companies and crude drug research activities.

\section{ACKNOWLEDGEMENT}

I wish to express my gratitude to Mr Dinesh Kumar for illustrations. I am grateful to Dr P. V. Prassana, Head of the Office, Central National Herbarium, Howarh, for facilities provided for study. Dr Milind M. Sardesai, Dr. Babasaheb Ambedkar Marathwada University, Aurangabad and Dr Yen-Hsuesh Tseng, National University, Taiwan have helped me with some valuable literatures. I also express my gratitude to Dr H. B. Singh and Dr V. Ranjan and for his valuable suggestions. I thank Dr P Singh, Director, Botanical Survey of India, Kolkata for infrastructure provided during study.

\section{CONFLICT OF INTEREST}

There is no conflict of interest.

\section{ABBREVIATION USED}

CAL: Central National Herbarium, Howrah; SEM: Scanning Electron Microscope.

\section{REFERENCES}

1. Bharati KA, Singh HB. Crude drug identification: A case study (part 2), J Res Ayurveda Siddha. 2015;1:13-31.

2. Bone K. The Impact of Quality issues on the safety of herbal products. In: Mills SK, Bone K, editor. The essential guide to herbal safety. Elsevier: Churchill Livingstone;2005. p. 106-18.

3. Anonymous. Wealth of India. New Delhi: CSIR-NISCAIR;1952-2006.

4. Nadkarni KM. Indian Materia Medica, Vol. 1-2. Bombay: Popular book depot; 1954.

5. Ray PG, Majumdar SK. Antimicrobial activity of some Indian plants. Eco Bot 1976;30(40):317-20.

6. Sumanth M, Mustafa SS. Antistress, adoptogenic activity of Sida cordifolia roots in mice. Indian J Pharm Sci. 2009;71(3):323.

7. Anonymous. The useful plants of India. New Delhi: CSIR-NISCAIR;2006.

8. Pattar PV, Jayaraj M. Pharmacognostic and Phytochemical investigation of Sida cordifolia L-a threatened medicinal herb. Int J Pharm Pharm Sci 2012;1;87(1):36-40.

9. Selvadurai S, Senthamarai R, Kirubha TSV, Nishanthi M, Vijayakumar B. Pharmacognostic evaluation of whole plant of Sida spinosa Linn (Malvaceae). Int J Novel Trends Pharm Sci. 2012;2(1):42-6.

10. Navas M, Dan M, Latha PG. Comparative root anatomy of the species under Sida rhombifolia complex (Malvaceae). Pharmacogn J. 2013;5(6):269-74.

11. Sharma V, Mehta SC, Sinoriya P. Pharmacognostical Study of the Whole Plant of Sida rhombifolia. J Pharmacogn Phytochem. 2013;2(3):1-4.

12. Rao TR, Dave Y. Histo-architecture of the pericarp and seed liberation in the schizocarpic fruit of Sida rhombifolia L (Malvaceae). Pakistan J Bot. 2006;38(2):353

13. Sivarajan VV, Pradeep AK, George EJ. Mericarp morphology of Indian species of Sida L(Malvaceae) in relation to taxonomy. J Taiwan Mus. 1992;45(1):65-73.

14. Anonymous. Flora of India, Vol 3. Kolkata: BSI, Kolkata;1993.

15. Paul TK, Nayar MP. A scanning electron microscope survey of seed surface morphology of some taxa of Malavace. Bull Bot Surv India. 1987;29(1-4):226-52.

16. Vos $P$, Hogers $R$, Bleeker $M$, Reijans $M$, Van de Lee T, Hornes $M$, et al. AFLP: a new technique for DNA fingerprinting. Nucl Acids Res. 1995;23(21):4407-14.

17. Aguilar JF, Paul AF, Jansen R K. Phylogenetic Relationships and Classification of the Sida Generic Alliance (Malvaceae) Based on nrDNA ITS Evidence. Syst Bot. 2003;28(2):352-64.

18. Thul ST, Srivastava AK, Singh SC, Shanker K. Genetic and chemical diversity 
of high mucilaginous plants of Sida complex by ISSR markers and chemical fingerprinting. Molec Biotech 2011;49(1):77-81.

19. Waalkes JVB. Malesian Malvaceae revised. Blumea. 1966;14(1):177-203.

20. Bhandari MM. A new species of Sida (Malvaceae) from the Indian Desert. Ann Arid Zone. 1977,16(4):455-57.

21. Mathew P, Sivarajan VV. Sida elongata Blume and S javensis Cav (Malvaceae), new records for India. J Eco Taxon Bot 1983;4:617-19.

22. Sivarajan VV, Pradeep AK. Malvaceae of Southern Peninsular India: A Taxonomic Monograph. New Delhi: Daya Publishing House;1996.
23. Sivarajan VV, Pradeep AK. Sida fryxellii, a new species of Malvaceae from peninsular India. Kew Bull. 1990;725-27.

24. Sivadasan M, Kumar NA. Sida ravii, a new species of Malvaceae from India. Willdenowia. 1996;651-54.

25. Pradeep AK, Sivarajan VV. Sida linifolia Cav (Malvaceae): a new record for India Rheeda. 1993;3(1):22-5.

26. Sivarajan V, Mathew P. Flora of Nilambur (Western Ghats, Kerala). Dehra Dun: Bishen Singh Mahendra Pal Singh;1997.

27. Marais W. Notes on Mascarene Malvaceae. Kew Bull 1983;41-6.

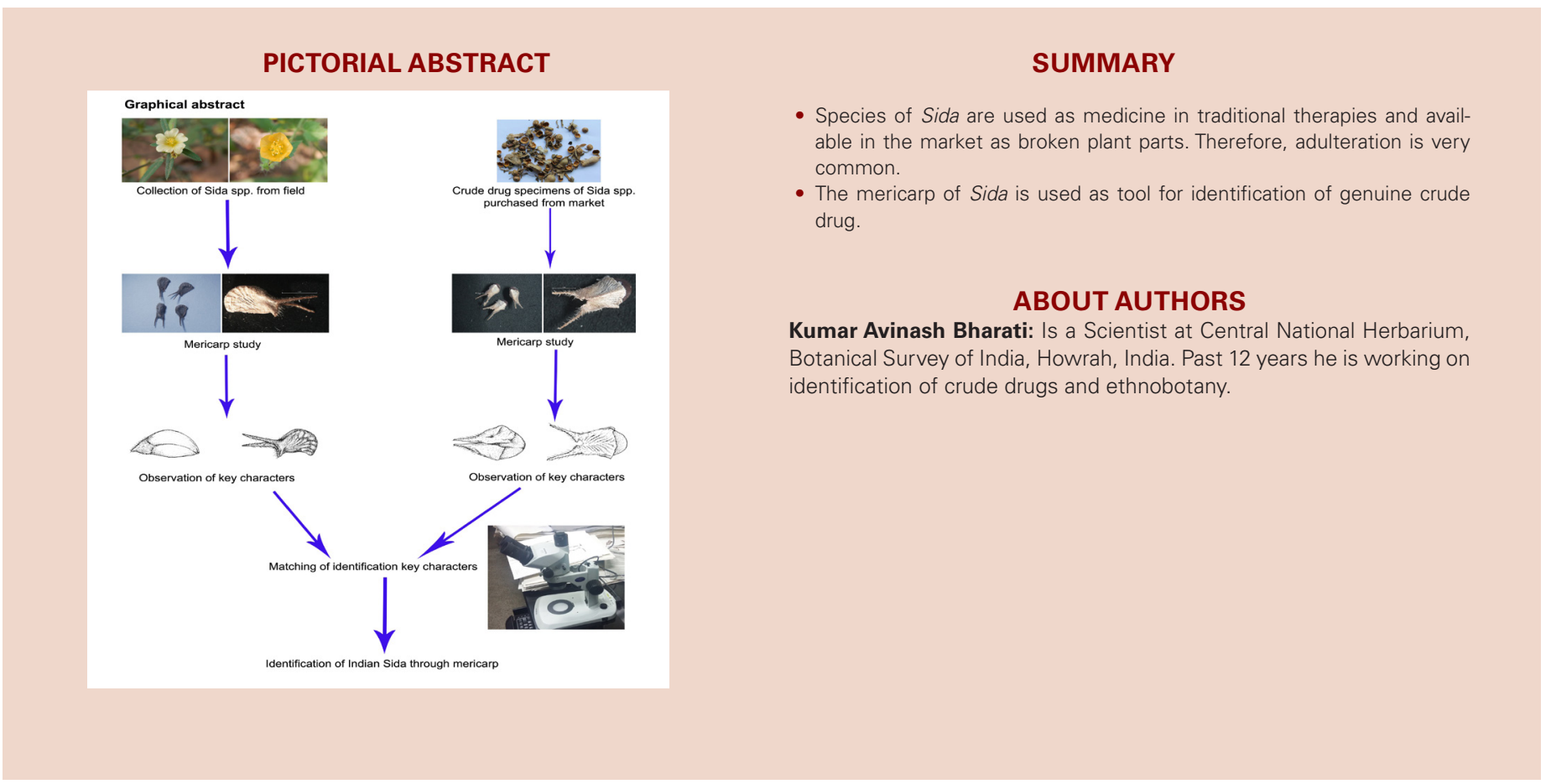

